\title{
KOMPETENSI MANAJERIAL KEPALA SEKOLAH DALAM UPAYA PENGEMBANGAN KUALITAS TENAGA PENDIDIK
}

\author{
Dienha Habibie \\ SMK Al Tafaqquh Fiddin Sindangwangi, Majalengka \\ abiemanyoe19@gmail.com
}

\begin{abstract}
Improving the quality of teaching staff is one of the important issues and is considered necessary to get serious attention and treatment from various parties concerned. This is closely related to school leadership and management. The success of educational institutions in carrying out the planned program needs to be supported by a principal's leadership, bearing in mind that leadership is a driving force for the resources owned by the institution. In general, this study aims to find out about the leadership management of school principals as managers in an effort to improve the quality of work of educators in the SMK Al Tafaqquh Fiddin. This research uses a qualitative approach with a case study method. This study describes the role of school principals in efforts to improve the quality of teaching staff. Based on the results of research that has been carried out, the strategy of the Principal of the Al Tafaqquh Fiddin Majalengka Vocational School in an effort to improve the quality of the teaching staff is by conducting a collaborative strategy. This means looking at and paying attention to his personal behavior and the situation or situation of the teaching staff, listening to ideas and suggestions from the teaching staff, resolving and clarifying errors on the principal's personal and teachers' errors, expressing desires, giving input and trying to solve the problems of the teaching staff, sharing shared tasks, set an example, act according to the capacity of educators, give more attention to the diligent.
\end{abstract}

Keywords: leadership, principal strategy, quality of educators

\section{ABSTRAK}

Peningkatan kualitas tenaga pendidik merupakan salah satu masalah penting dan dianggap perlu untuk mendapatkan perhatian dan penanganan yang serius dari berbagai pihak yang terkait. Hal ini berhubungan erat dengan kepemimpinan dan manajemen sekolah. Keberhasilan institusi pendidikan dalam menjalankan program yang telah direncanakan perlu didukung dengan sebuah kepemimpinan kepala sekolah, mengingat kepemimpinan merupakan motor penggerak bagi sumber daya yang dimiliki oleh lembaga. Secara umum penelitian ini bertujuan untuk mengetahui tentang manajemen kepemimpinan kepala sekolah sebagai manajer dalam upaya meningkatkan kualitas kerja tenaga pendidik yang ada di SMK Al Tafaqquh Fiddin. Penelitian ini menggunakan pendekatan kualitatif dengan metode studi kasus. Penelitian ini mendeskripsikan tentang peranan kepala sekolah dalam upaya meningkatkan kualitas tenaga pendidik. Berdasarkan hasil penelitian yang telah dilaksanakan, strategi kepala sekolah SMK Al Tafaqquh Fiddin Majalengka dalam upaya meningkatkan kualitas tenaga pendidik adalah dengan melakukan strategi kolaboratif. Artinya memandang dan memperhatikan terhadap perilaku pribadinya dan situasi atau keadaan para tenaga pendidik, mendengarkan ide dan saran dari para tenaga pendidik, menyelesaikan dan mengklarifikasi kesalahan pada pribadi kepala sekolah dan kesalahan tenaga pendidik, mengemukakan keinginan, memberikan masukan dan berusaha memecahkan masalah tenaga pendidik, membagi tugas secara bersama, memberikan teladan, bertindak sesuai dengan kemampuan tenaga pendidik, memberikan perhatian yang lebih terhadap yang rajin.

Kata kunci : kepemimpinan, strategi kepala sekolah, kualitas tenaga pendidik

Submitted May 16, 2020 | Revised Jun 15, 20xx | Accepted Jun 20, 2020 


\section{Pendahuluan}

Sekolah sebagai lembaga pendidikan formal memiliki tujuan untuk membentuk manusia yang berkarakter, dalam mengembangkan intelektual peserta didik dalam rangka mencerdaskan kehidupan bangsa. Kepala sekolah sebagai pemimpin pendidikan perannya sangat penting untuk membantu guru dan muridnya. Didalam kepemimpinnya kepala sekolah harus dapat memahami, mengatasi dan memperbaiki kekurangan-kekurangan yang terjadi di lingkunagn sekolah.

Untuk meningkatkan kualitas pendidikan seorang kepala sekolah harus mampu meningkatkan kinerja para guru atau bawahannya. Banyak faktor yang dapat mempengaruhi kinerja sesorang, sebagai pemimpin sekolah harus mampu memberikan pengaruh-pengaruh yang dapat menyebabkan guru tergerak untuk melaksanakan tugasnya secara efektif sehingga kinerja mereka akan lebih baik. Sebagai pemimipin yang mempunyai pengaruh, ia berusaha agar nasehat, saran dan jika perlu perintahnya diikuti oleh guru-guru. Dengan demikian ia dapat mengadakan perubahan-perubahan dalam cara berfikir, sikap, tingkah laku yang dipimpinnya.

Dalam melaksanakan fungsi kepemimpinannya kepala sekolah harus melakukan pengelolaan dan pembinaan sekolah melalui kegiatan administrasi, manajemen dan kepemimpinan yang sangat tergantung pada kemampuannya. Disamping itu kepala sekolah sebagai pemimpin pendidikan berfungsi mewujudkan hubungan manusiawi (buman relationship) yang harmonis dalam rangka membina dan mengembangkan kerjasama antar personal, agar secara serempak bergerak kearah pencapaian tujuan melalui kesediaan melaksanakan tugas masing-masing secara efisien dan efektif.

Keberhasilan manajemen suatu lembaga pendidikan sangat tergantung pada kepemimpinan kepala sekolah. Sebagai pemimpin di sebuah lembaga, maka dia harus mampu membawa lembaga tersebut ke arah tercapainya tujuan yang telah ditetapkan, dia harus mampu melihat adanya perubahan serta mampu melihat masa depan dalam kehidupan globalisasi yang lebih baik. Menurut (Susanto, 2016) Keterampilan konsep berarti pemimpin sekolah mampu melihat organisasi sebagai keseluruhan dan menyelesaikan masalah untuk kebermanfaatan bagi setiap orang di dalam organisasi.Kepala sekolah harus bertanggung jawab atas kelancaran dan keberhasilan semua urusan pengaturan dan pengelolaan sekolah secara formal kepada atasannya dan secara informal kepada masyarakat yang telah menitipkan anak didiknya. Kepala sekolah sebagai seorang pendidik, administrator, pemimpin dan supervisor, diharapkan dengan sendirinya dapat mengelola lembaga pendidikan ke arah perkembangan yang lebih baik dan dapat menjanjikan masa depan.

Sementara itu efektivitas kualitas dan perilaku kepala sekolah dapat dinilai dari kinerjanya dalam mengaktualisasikan fungsi dan perannya sebagai kepala sekolah, meliputi: pendidik (edukator), manajer, administrator, supervisor, pemimpin (leader), inovator, motivator dan kewirausahaan, sering disingkat dengan EMASLIMW. Kepala sekolah memiliki tanggung jawab yang besar di dalam merencanakan, mengorganisir, membina, melaksanakan serta mengendalikan sekolah dan sumber daya manusia yang ada di dalamnya(Kompri, 2017).

Usaha perbaikan dan peningkatan kualitas tenaga pendidik ini sangat penting dilakukan dalam rangka mempersiapkan guru yang mampu menjadi subyek dan bisa berperan di lingkungan masyarakat sekaligus menampilkan keunggulan dirinya yang tangguh, kreatif, mandiri dan profesional pada bidang masing-masing. 
Perilaku dan kinerja kepala sekolah merupakan hal yang sangat penting dalam menunjang keberlangsungan jalannya proses pendidikan yang baik dan berkualitas di sekolah. Kualitas kepala sekolah akan menentukan pula kualitas sumber daya manusia baik itu kualitas tenaga pendidik maupun tenaga kependidikan.

Fenomena yang terjadi tiga tahun terakhir ini di SMK Al Tafaqquh Fiddin adalah adanya kepemimpinan kepala sekolah pada tahun 2016 hingga 2018 yang dinilai tidak kurang baik itu dalam hal administrasi maupun di lapangan yang ternyata memberikan imbas negatif terhadap kualitas tenaga pendidik yang ada pada sekolah tersebut. Hal itu menyebabkan mengharuskan adanya pergantian kepala sekolah pada tahun awal ajaran 2018/2019, yang kemudian dirasakan membawa perubahan yang lebih positif serta dirasakan mampu meningkatkan kualitas tenaga pendidik yang ada pada sekolah tersebut. Hal ini selaras dengan informasi yang didapatkan oleh peneliti yang bersumber dari salah satu tenaga pendidik dan kepala sekolah yang saat ini memimpin di SMK Al Tafaqquh Fiddin. Berdasarkan hal tersebut, peneliti merasa tertarik untuk kemudian memunculkan fenomena tersebut untuk kemudian dijadikan sebagai bahan penelitian. Sehingga akan didapat informasi diantaranya adalah tentang strategi apa yang dilakukan oleh kepala sekolah SMK Al Tafaqquh Fiddin saat ini sehingga mampu meningkatkan kembali kualitas tenaga pendidik pada sekolah tersebut.

\section{Metode Penelitian}

Bertitik tolak dari pemikiran dan permasalahan di atas, metodologi yang digunakan dalam penelitian ini adalah penelitian kualitatif, yaitu strategi dan teknik penelitian yang digunakan untuk memahami masyarakat dengan sebanyak mungin mengumpulkan fakta yang mendalam, data disajikan dalam bentuk verbal, bukan dalam bentuk angka. Pendekatan kualitatif memiliki karakteristik alami sebagai sumber data langsung, deskriptif, proses lebih dipentingkan dari pada hasil, analisis dalam penelitian kualitatif cenderung dilakukan secara analisa induktif dan makna merupakan hal yang esensial (Moleong, 2002). Penilitian kualitatif bersifat subyektif dan refleksif. Dalam penelitian kualitatif tidak digunakan instrument standar, tetapi penelitian berperan sebagai instrument (Sukmadinata, 2013). Pengamatan dapat dilakukan tanpa dan dengan partisipasi peneliti. Mengamati sambil berpartisipasi dapat menghasilkan data yang lebih banyak, lebih mendalam dan lebih terperinci. Agar menjadi partisipan dan sekaligus pengamat, peneliti hendaknya turut serta dalam berbagai peristiwa dan kegiatan, tapi ada kalanya peneliti hanya dapat menjadi pengamat tanpa berperan sebagai partisipan (Nasution, 1988).

Penelitian ini dilakukan di SMK Al Tafaqquh Fiddin Majalengka. Penelitian ini mendeskripsikan tentang peranan kepala sekolah dalam upaya meningkatkan kualitas tenaga pendidik. Berdasarkan hasil penelitian yang telah dilaksanakan, strategi kepala sekolah SMK Al Tafaqquh Fiddin Majalengka dalam upaya meningkatkan kualitas tenaga pendidik adalah dengan melakukan strategi kolaboratif.

\section{Hasil dan Pembahasan}

Kepala Sekolah dalam membina bawahan, utamanya para tenaga pendidik sangat dituntut dan sangat diperlukan, sebab tenaga pendidik merupakan alat utama dalam 
menciptakan tujuan pembelajaran di sekolah. Dari seorang tenaga pendidiklah ilmu pengetahuan dan agama akan mengalir ke siswa. Karenanya dalam mencapai tujuan pembelajaran yang efektif dan efisien, kepala sekolah sangat dituntut untuk meningkatkan profesionalisme tenaga pendidik. SMK Al Tafaqquh Fiddin Sindangwangi merupakan salah satu lembaga pendidikan di Kabupaten Majalengka yang juga memperhatikan peningkatan kualitas tenaga pendidik. Dari hasil wawancara dan juga observasi yang peneliti lakukan di sekolah ini terjadi peningkatan kualitas tenaga pendidik yang cukup signifikan. Hal ini disebabkan gaya kepemimpinan Kepala Sekolah dalam meningkatkan kualitas para tenaga pendidik.

Sebagai temuan diperoleh data bahwa strategi peningkatan kualitas tenaga pendidik disebabkan oleh beberapa strategi yang dilakukan oleh kepala sekolah, di antaranya:

a. Strategi kepala sekolah dalam meningkatkan kompetensi kepribadian.

Adalah suatu kompetensi yang memiliki kemampuan personal yang mencerminkan kepribadian yang mantap, stabil, dewasa, arif dan berwibawa, menjadi teladan peserta didik, dan berakhlak mulia. Tenaga pendidik sebagai teladan akan mengubah prilaku siswa, tenaga pendidik adalah panutan. Tenaga pendidik yang baiak akan dihormati dan disegani oleh siswa. Jadi tenaga pendidik harus bertekad mendidik dirinya sendiri lebih dulu sebelum mendidik orang lain. Pendidikan melalui keteladanan adalah pendidikan yang paling efektif. Tenaga pendidik yang disenangi, otomatis mata pelajaran yang ia ajarkan akan disenangi oleh siswa, dan siswa akan semangat dan termotivasi sendiri mendalami mata pelajaran tersebut.

b. Strategi kepala sekolah dalam meningkatkan kompetensi profesional.

Adalah suatu kompetensi yang memiliki kemampuan penguasaan materi pelajaran secara luas dan mendalam, serta metode dan teknik mengajar yang sesuai yang dipahami oleh murid, mudah ditangkap, tidak menimbulkan kesulitan dan keraguan, yang mencakup penguasaan materi kurikulum mata pelajaran di sekolah dan subtansi keilmuan yang menaungi materinya, serta penguasaan terhadap struktur dan metodologi keilmuannya

c. Strategi kepala sekolah dalam meningkatkan kompetensi sosial.

Adalah suatu kompetensi yang memiliki kemampuan tenaga pendidik untuk berkomunikasi dan berinteraksi secara efektif dengan lingkungan sekolah dan di luar lingkungan sekolah. Tenaga pendidik profesional berusaha mengembangkan komunikasi dengan orang tua siswa, sehingga terjalin komunikasi dua arah yang berkelanjutan antara sekolah dan orang tua, serta masyarakat pada umumnya.

\section{Kesimpulan}

Dari hasil penelitian yang telah dilaksanakan, strategi kepala sekolah SMK Al Tafaqquh Fiddin Majalengka dalam upaya meningkatkan kualitas tenaga pendidik adalah dengan melakukan strategi kolaboratif. Artinya memandang dan memperhatikan terhadap perilaku pribadinya dan situasi atau keadaan para tenaga pendidik, mendengarkan ide dan saran dari para tenaga pendidik, menyelesaikan dan mengklarifikasi kesalahan pada pribadi kepala sekolah dan kesalahan tenaga pendidik, mengemukakan keinginan, memberikan masukan dan berusaha memecahkan masalah tenaga pendidik, membagi tugas secara bersama, memberikan teladan, bertindak sesuai dengan kemampuan tenaga pendidik, memberikan perhatian yang lebih terhadap yang rajin. 
Kepala sekolah dalam melaksanakan kepemimpinannya pada sekolah tersebut berfokus pada 1.) Kompetensi Kepribadian, 2). Kompetensi Profesional, dan 3). Kompetensi Sosial. Dari kompetensi tersebut kepala SMK Al Tafaqquh Fiddin terus mengupayakan agar kualitas para tenaga pendidik yang ada pada sekolah tersebut terus meningkat sehingga juga akan berpengaruh terhadap kualitas hasil belajar siswa serta iklim sekolah yang jauh lebih baik.

\section{Daftar Pustaka}

Ahmad Susanto. (2016). Manajemen Peningkatan Kinerja Guru Konsep, Strategi, Dan Implementasinya. Jakarta: Prenada Media Grup.

Kompri, (2017). Standardisasi Kompetensi Kepala Sekolah: Pendekatan Teori Untuk Praktik Profesional Edisi Pertama.Jakarta: Kencana Prenada Media.

Lexy J. Moleong. (2005). Metodologi Penelitian Kualitatf, Bandung: Remaja Rosda Karya.

Nasution, S. (1988). Penelitian Naturalistik Kualitatif. Bandung: Tarsito.

Novianty Djafri. (2016). Manajemen Kepemimpinan Kepala Sekolah. (Yogyakarta: Deepublish Publisher,

Permendiknas Nomor 13 Tahun 2007 Tentang Standar Kepala Sekolah/Madrasah

Undang-undang Republik Indonesia Nomor 13 tentang Standar Kepala Sekolah/Madrasah. (2007). 